\title{
Influence of Osmotic Dehydration on Ascorbic Acid Loss in Pickled Dry Peppers (Capsicum chinense)
}

\author{
Tissiane Mayara da Silva ${ }^{1}$, Eliana Janet Sanjinez Argandoña ${ }^{2}$, Grasiele Scaramal \\ Madrona $^{1}$, Izabel Cristina Freitas Moraes $^{3}$, Charles Windson Isidoro Haminiuk ${ }^{4}$ and \\ Ivanise Guilherme Branco ${ }^{5 *}$ \\ ${ }^{1}$ Universidade Estadual de Maringá; Av. Colombo, 5790; 87020-900; Maringá - PR - Brasil. ${ }^{2}$ Universidade Federal \\ de Dourados; Rua João Rosa Góes, 1761; 79825-070; Dourados - MS - Brasil. ${ }^{3}$ Universidade de São Paulo, Rua \\ Duque de Caxias Norte, 225; 13635-000; Pirassununga - SP - Brasil. ${ }^{4}$ Universidade Tecnológica Federal do \\ Paraná; BR 369, Km 0,5; 87301-006; Campo Mourão - PR - Brasil . 'Universidade Estadual Paulista; Av. Dom \\ Antônio, 2100; 19806-900; Assis - SP - Brasil
}

\begin{abstract}
The objective of this work was (1) to develop a dehydrated pepper with 45\% humidity, determining the drying curves for pepper, with and without osmotic pre-treatment and (2) to evaluate the influence of both drying and osmotic treatment on the content ascorbic acid (vitamin $C$ ) in fresh pepper and pepper with 45\% humidity. The experiments were carried out using the peppers cut in half, with and without osmotic pre-treatment, followed by drying in an oven at $70{ }^{\circ} \mathrm{C}$. The results showed that the osmotic pretreatment did not influence the retention of ascorbic acid during the drying of pepper. The sensory analysis regarding the color, flavor, and texture attributes revealed that there was no difference in the acceptability.
\end{abstract}

Key words: Capsicum chinense, ascorbic acid, osmotic dehydration, drying

\section{INTRODUCTION}

The genus Capsicum, which belongs to the family Solanaceae, includes peppers of important economic value. There are several Capsicum species; some of them are widely spread, such as C. annuum, C. frutescens, C. baccatum, $C$. pubescens, and $C$. chinense. In Brazil, $C$. baccatum and $C$. chinense are the predominant species for commercial hot peppers (Lannes et al 2007).

The "Moema" pepper or "biquinho pepper", as it is named in Brazil, is one example of pepper that belongs to the Capsicum chinense (Bontempo 2007). It has been developed by the Brazilian Agricultural Research Corporation (Embrapa) and is usually appreciated by those who like peppers but do not appreciate the pungency typically found (Bontempo 2007). The species of this genus are commonly known as sweet and hot peppers and are divided into two groups: pungent (spicy) and non-pungent (sweet). The sweet/hot characteristic is achieved by the presence of capsaicinoid, primarily capsaicin, an alkaloid of the genus Capsicum that is found in the seed and in the placenta of the fruit (Wyk and Wink 2004).

The species of the genus Capsicum have great economic significance within the group of hot spices in many tropical, sub-tropical, and temperate countries. This kind of peppers grows in different parts of the world, being China and Turkey as the major producers of species of

*Author for correspondence: igbranco@assis.unesp.br 
Capsicum (chili peppers) (Yaldiz et al. 2010), while the Thais and Koreans are the biggest consumers, consuming on average up to eight grams per person per day (Reifschneider 2004).

Nowadays, Brazil has a considerable production of peppers and states such as Minas Gerais, São Paulo, Ceará, and Rio Grande do Sul, account for the majority of Brazilian pepper production (Madail et al. 2005). The growing market demand, estimated at more than 100 million reais a year, has triggered both the increase in cultivated areas and the establishment of agro-industries and agribusiness, making sweet and spicy peppers one of the most important agricultural commodities in the country (Napoleão 2006). Red peppers, for example, are the third most produced and consumed vegetable for seasoning in Brazil, behind only of garlic and onion (Reifschneider 2000).

In 2005, the volume of Brazilian exports reached 9,222 tons of sweet peppers, a U.S.\$ 23.478 million worth market, making peppers the second most relevant vegetable export, after melon export. Although Brazilian consumption of chili is still small compared to other vegetables, new market prospects have been encouraging this culture. In addition, the development of new products based on processed peppers has contributed to significant earned value of this vegetable (Napoleão 2006).

Peppers have a wide variety in their chemical composition, having capsaicinoid, carotenoids, and ascorbic acid as its main components. Other components such as phenolic compounds, vitamin $\mathrm{A}$, and tocopherols are also present and their levels may vary with genotype and degree of maturation (Deepa et al 2007; Kappel 2008).

Capsaicinoids are found to exert multiple pharmacological and physiological effects, including analgesia, anticancer, antiinflammation, antioxidant, and anti-obesity. In addition, capsaicinoids also display benefits on cardiovascular and gastrointestinal system. Sweet peppers are the source of natural capsinoids, which share similar structure with capsaicinoids.

Compared to capsaicinoids, capsinoids are less pungent and easily broken down in the normal aqueous conditions. So far, it has been found that capsinoids have biological properties such as antitumor, antioxidant, and anti-obesity. Since capsinoids are less toxic than capsaicinoids, the former may have advantages over latter in clinical applications such as cancer prevention and weight loss (Luo et al. 2011).
Studies have shown that species of Capsicum have medicinal properties; they act as topical analgesic, tonic, antiseptic, carminative, and counterirritant. These species have been used for a number of illnesses such as rheumatism, arthritis, neuralgia, itching, lumbago, and spasms (Wyk and Wink 2004).

However, like any product "in natura", the presence of enzymes, microorganisms, and other agents make the "Moema" pepper consumption restricted to a short period of time and susceptible to degradation. Thus, dehydration, or drying, is an alternative for its preservation.

The removal of water to a level where microbial growth is minimized brings advantages such as weight reduction and product availability throughout seasons (Park et al. 2001). However, dehydration not only reduces the product moisture, but it also reduces nutrient contents, color, and other important characteristics of food (RaoultWack et al. 1989; Sanjinez-Argandoña et al. 2010).

Therefore, the control of the dehydration process is essential to conserve the nutritional characteristics of the food. Ascorbic acid (vitamin C), for example, is very sensitive and may degrade in various forms, primarily due to temperature, salt, and/or sugar concentration, $\mathrm{pH}$, oxygen, enzymes, and others (Fennema 1993). Particularly with peppers, the process of dehydration causes loss of ascorbic acid due to the application of high temperatures.

In the aforementioned context, the present work aimed to develop a preserved pepper dehydrated to $45 \%$ humidity, with and without osmotic pretreatment and then carry out the assessment in product acceptance. Additionally, the influence of osmotic dehydration on the ascorbic acid content was assessed.

\section{MATERIALS AND METHODS}

\section{Materials}

The Moema pepper used in this work was obtained from a local market in the city of Maringa, State of Parana.

\section{Methods}

Preparation of osmotic solution

Sucrose and sodium chloride in the proportion of $1: 3 \quad(30 \%$ concentration) were utilized as 
dehydrating solution. They were purchased from the local market.

\section{Osmotic dehydration}

After selection and cleaning of the peppers, about $250 \mathrm{~g}$ were cut lengthwise then, the seeds were removed and the contents wereimmersed in a 1000 $\mathrm{ml}$ of osmotic solution at room temperature (25 ${ }^{\circ} \mathrm{C}$ ) for 90 minutes. Then the liquid was drained and the peppers were dried on paper towels.

\section{Determination of the drying curve}

Peppers, with and without osmotic pre-treatment were dispersed on perforated trays and dried in at $70^{\circ} \mathrm{C}$ an oven with air recirculation. The peppers were weighed every ten minutes during the first two hours. After that, the weighing was performed every twenty minutes until it reached equilibrium. The drying curve was obtained by measuring the decrease in humidity with time. The period of time required to obtain the peppers with $45 \%$ humidity (45g water/100 g sample) was calculated through the drying curve.

\section{Pickle Preparation}

Pickled pepper was prepared by two different procedures. First, the pepper was osmotically pretreated and then dehydrated. In the second procedure, the pepper was dehydrated without osmotic treatment. The dehydration process of peppers included the following steps: (1) placement of pepper in sterilized glass jars, (2) addition of a sauce that covered the entire content. The sauce was prepared with $75 \%$ soybean oil, $23 \%$ olive oil and $2 \%$ of seasoning (dehydrated garlic, oregano, basil, and bay leaf). After the addition of the sauce, the picked pepper was subjected to heat treatment at $80{ }^{\circ} \mathrm{C}$ for 20 minutes.

\section{Content of vitamin C}

The ascorbic acid (vitamin C) content was determined in both, the fresh pepper and dried pepper with and without osmotic pretreatment according to the AOAC methodology (1996), modified by Benassi and Antunes (1988).

\section{Sensory Analysis}

The sensory evaluation of canned dried pepper, with and without prior osmotic dehydration was carried out by a team of 50 untrained judges of both the sexes. Judges evaluated the samples of roasted and salted peppers, which were coded with three-digit numbers and presented randomly among the judges. The acceptability of the canned pepper was evaluated according to the color, flavor, and texture utilizing the hedonic scale where extremes like 1 meant disliked extremely and 9 was liked extremely. The statistical analysis was performed using the analysis of variance (ANOVA).

\section{RESULTS AND DISCUSSION}

\section{Analysis of Ascorbic Acid}

Table 1 shows the results of vitamin $\mathrm{C}$ content in fresh and dried pepper, treated or not prior to osmotic dehydration.

Table 1 - Ascorbic acid concentration of pickled fresh and dehydrated pepper (Capsicum chinense) with and without previous osmotic treatment.

\begin{tabular}{|c|c|c|}
\hline Samples & Ascorbic acid concentration (mg / 100 g) & Maintenance of ascorbic acid (\%) \\
\hline Fresh pepper & 223.3 & - \\
\hline $\begin{array}{l}\text { Dried pepper without } \\
\text { osmotic pretreatment }\end{array}$ & 55.30 & 24.8 \\
\hline $\begin{array}{l}\text { Dried pepper with osmotic } \\
\text { pretreatment }\end{array}$ & 39.00 & 17.5 \\
\hline
\end{tabular}

The results showed $233 \mathrm{mg}$ of ascorbic acid per $100 \mathrm{~g}$ of pepper, which was close to the values obtained by Bontempo (2007) but was higher than the value reported by Chuah et al. (2008) that found $191 \mathrm{mg}$ of ascorbic acid per $100 \mathrm{~g}$ of paprika pepper; by Vega-Gálvez et al. (2009) that observed $188.2 \mathrm{mg}$ ascorbic acid per100 $\mathrm{g}$ fresh red pepper; and by Castro et al. (2008) that obtained $107.4 \mathrm{mg}$ ascorbic acid per $100 \mathrm{~g}$ fresh red pepper. Differences in the amount of ascorbic acid could be attributed to the variations in farming, genetics, maturation, fertilizers, and environmental conditions (Howard, 2000; Deppa et al. 2007). 
About 24.8\% of ascorbic acid retention was observed in the dried peppers without osmotic pretreatment, while $17.5 \%$ of retention was obtained in the peppers subjected to osmotic treatment prior to drying. The lower retention of ascorbic acid found in the pepper subjected to osmotic treatment could be due to the migration of ascorbic acid to the antioxidant osmotic solution. According to Sanjinez-Argandoña et al. (2005), the reduction of ascorbic acid content during the osmotic dehydration of pepper could be related to the partial degradation due to oxygen, light, and temperature exposure.

There are reports showing that exposure to oxygen, light, and temperature contributes to the oxidation of vitamin $\mathrm{C}$ in the drying process. Howard et al. (1994) found $75 \%$ decrease in total ascorbic acid in thermal processing of "jalapeño" cultivars. Vega-Gálvez et al. (2009) studied the effect of air-drying temperature $(50,60,70,80$ and $90{ }^{\circ} \mathrm{C}$ ) on ascorbic acid retention. They reported a maximum loss of $98.2 \%$ of vitamin $\mathrm{C}$ in red pepper dried at $90^{\circ} \mathrm{C}$.

Kim et al. (2006) compared the effect of modified drying (dried at $70{ }^{\circ} \mathrm{C} / 6 \mathrm{~h}$ in cut pods) with the conventional drying (dried at $80{ }^{\circ} \mathrm{C} / 5 \mathrm{~h}$, followed by $60{ }^{\circ} \mathrm{C} / 18 \mathrm{~h}$ in whole pods) in the changes of ascorbic acid by drying in Korean red pepper and observed that the modified drying was more effective in the retention of ascorbic acid.

The study done by Queiroz et al. (2008) identified losses between 32 to $68 \%$ of ascorbic acid when drying the guavas at $60{ }^{\circ} \mathrm{C}$ that were predehydrated by immersion/impregnation in different solutes.

Although there were losses of vitamin $\mathrm{C}$ due to dehydration with or without osmotic treatment, the remaining ascorbic acid concentration in pepper was higher than the values reported in the literature for fresh fruits such as cashew (126 $\mathrm{mg} / 100 \mathrm{~g}$; Souza-Filho et al. 1999), orange (83.78 $\mathrm{mg} / 100 \mathrm{~g}$; Da Silva et al. 2006), strawberry (59.4 $\mathrm{mg} / 100 \mathrm{~g}$; Calegari et al. 2002), and passion fruit $(15,4 \mathrm{mg} / 100 \mathrm{~g}$; Righetto et al. 1999).

\section{Drying Kinetics}

Figure 1 shows the kinetic behavior of moisture loss with time during the process of drying the pepper with and without osmotic pretreatment. It was observed that water loss up to about 350 minutes was approximately equal for both the treatments. After that time, there was higher water loss in the pepper with osmotic pretreatment and, consequently, less drying time. This behavior could be attributed to the softening of the tissue during the osmotic pretreatment, favoring the migration of water vapor during the drying process. Drying time for the samples submitted to osmotic treatment was lower (approximately $10 \mathrm{~h}$ ) compared to the sample without pretreatment (11 h).

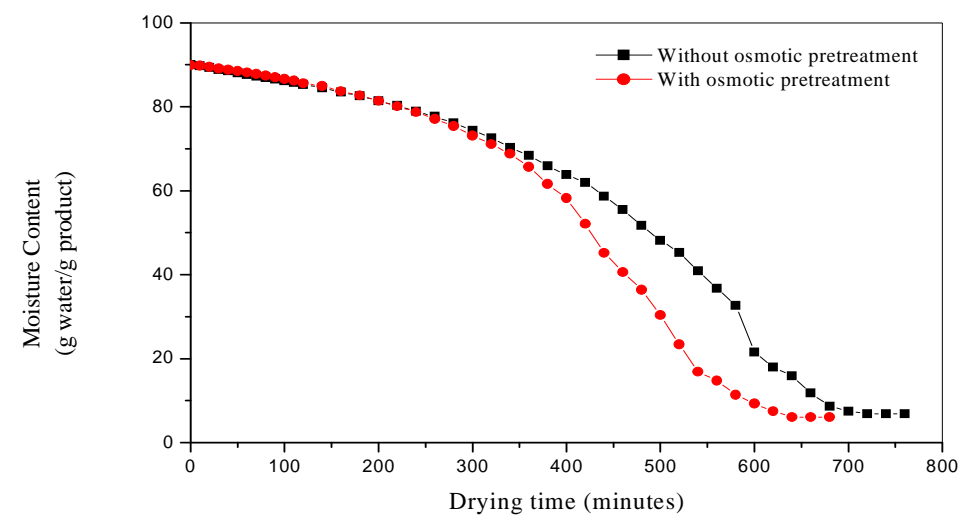

Figure 1 - Moisture content wet basis (WBU) of Capsicum chinense, with and without osmotic

Opposite results occurred with the untreated pepper, which showed a lower rate of water loss during the drying process and, consequently, a longer drying time. All the tested samples of pepper had very similar performance. The ones subjected to osmotic pre-treatment reached equilibrium after $10 \mathrm{~h}$ of drying, while the ones without pretreatment reached equilibrium after 11 $\mathrm{h}$ of drying. 
Figure 2 shows the curves of moisture content on dry basis (WBS) of pepper, with and without osmotic pretreatment.

\section{Sensory Analysis}

Table 2 presents mean scores obtained for the sensory attributes of color, flavor, and texture of canned pepper.

The values attributed by the testers for all the attributes were higher than 6.0 ("like slightly").
The analysis of variance (ANOVA) showed no significant difference between the pickled peppers prepared from the chili without osmotic pretreatment and with osmotic pretreatment with a $5 \%$ level of significance regarding color, flavor, and texture. Therefore, the immersion time of pepper in the osmotic solution could have been insufficient to influence the sensory characteristics of the final product.

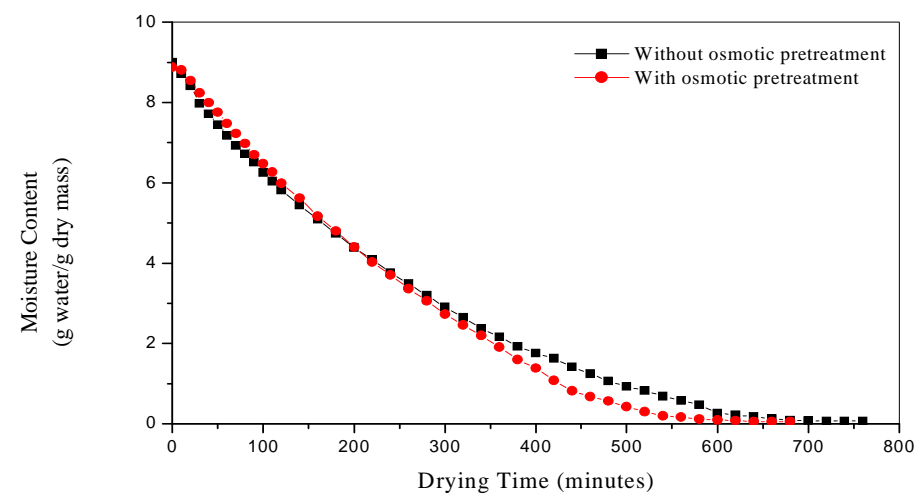

Figura 2 - Moisture content on dry basis (WBS) of Capsicum chinense, with and without osmotic pretreatment.

Table 2 - Mean ratings of pickled pepper (Capsicum chinense) dehydrated with 45\% humidity.

\begin{tabular}{ccc}
\hline Attribute & $\begin{array}{c}\text { Pickled peppers without } \\
\text { osmotic pretreatment }\end{array}$ & $\begin{array}{c}\text { Pickled peppers with } \\
\text { osmotic pretreatment }\end{array}$ \\
\hline Color & $6.83 \mathrm{a}$ & $6.63 \mathrm{a}$ \\
Flavor & $6.40 \mathrm{a}$ & $6.86 \mathrm{a}$ \\
Texture & $6.30 \mathrm{a}$ & $6.43 \mathrm{a}$ \\
\hline
\end{tabular}

Means with same letters in the same line are not statistically different from each other $(\mathrm{p}<0.05)$.

Corrêa et al. (2008), studying the influence of immersion time in the osmotic dehydration of tomato (Lycopersicon esculentum), found that the tomatoes that remained less time $(0.5 \mathrm{~h}$ in osmotic pretreatment had higher sensory evaluation scores compared to the tomatoes that remained for a longer time (2.0 hours) immersed in the osmotic solution.

Another aspect that deserves attention is the texture characteristic because it is one of the main sensory attributes of food (Szczesniak 2002). Elias et al. (2008), for example, evaluated the influence of pretreatment and drying on the texture. In their work, sensory evaluation of osmo-convective dried Fuyu persimmons showed good sensory acceptance being texture the sensory parameter that had the highest acceptance, and appearance the lowest acceptance. Vega-Gálvez et al. (2011) investigated the effect of air temperature on drying kinetics and quality characteristics of osmo-treated jumbo squid (Dosidicus gigas). They observed increase of texture with increasing of air-drying temperature probably due to changes in the food protein matrix.

In this study, both the products had the same acceptance for all the sensory attributes. Therefore, if the main interest would be the maintenance of sensory attributes with the highest level of vitamin $C$ content, the best practice would be not applying the osmotic pre-treatment to the product, confirming then $24.8 \%$ maintenance of ascorbic acid. However, if the interest is the reduction of the drying time, the application of osmotic dehydration is recommended. 


\section{CONCLUSION}

The osmotic pretreatment did not influence ascorbic acid retention during the drying process of pepper. However, the osmotic pretreatment reduced the drying time to obtain the pickled pepper dehydrated with $45 \%$ humidity.

The sensory analysis showed no difference in the acceptability between the products, regarding color, flavor, and texture attributes.

\section{REFERENCES}

A.O.A.C. Association of Official Agricultural Chemists. Official methods of analysis. HORWITZ W. (ed), $16^{\text {th }}$ ed., Gaithersburg, Maryland, 1997.

Benassi MT, Antunes AJA. A comparisson of metaphosphoric and oxalic acids as extractant solutions for the determination of vitamin $\mathrm{C}$ in selected vegetables. Braz Arch Biol Technol.1988; 31 (4): 507-513.

Bontempo M. Pimenta e seus benefícios à saúde., São Paulo: Alaúde Editorial; 2007.

Castro SM, Saraiva JA, Lopes da Silva JA, Delgadillo I, Loey AV, Smout C, Hendrickx M. Effect of thermal blanching and of high pressure treatments on sweet green and red bell pepper fruits (Capsicum annum L.). Food Chem. 2008; 107(4): 1436-1449.

Chuah AM, Lee Y, Yamaguchi T, Takamura H, Yin L, Matoba T. Effect of cooking on the antioxidant properties of coloured peppers. Food Chem. 2008; 111(1): 20-28.

Corrêa JLG, et al. Desidratação osmótica de tomate seguida de secagem. Rev Bras Prod Agroind. 2008; 10(1): 35-42.

Da Silva PT, Lopes MLM, Valente-Mesquita VL. Efeito de diferentes processamentos sobre o teor de ácido ascórbico em suco de laranja utilizado na elaboração de bolo, pudim e geléia. Ciênc Tecnol Alimen. 2006; 26(3): 678-682.

Deppa N, Kaur C, George B, Singh B, Kapoor H. Antioxidant constituents in some sweet pepper (Capsicum annuиm L.) genotypes during maturity. LWT-Food Sci Technol. 2007; 40 (1): 121-129.

Elias NF, Berbert PA, Molina MAB, Viana AP, Dionello RG, Queiroz VAV. Avaliação nutricional e sensorial de caqui cv Fuyu submetido à desidratação osmótica e secagem por convecção. Ciênc Tecnol Alimen. 2008; 28(2): 322-328.

Fennema OR. Química de los alimentos. $2^{\mathrm{a}}$ edição. Zaragoza: Acribia; 1993.

Howard LR, Smith RT, Wagner AB, Villalon B, Burns EE. Provitamin A and ascorbic acid content of fresh pepper cultivars (Capsicum annиum) and processed jalapeños. J Food Sci. (1994); 59(2): 362-365.
Howard LR, Taccott ST, Brenes CH, Villalon B. Changes in phytochemical and antioxidant activity of selected pepper cultivars (Capsicum species) as influenced by maturity. J Agric Food Chem. (2000); 48(5): 1713-1720.

Kappel VD, Costa GM, Scola G, Silva FA, Landell MF, Valente $\mathrm{P}$ et al. Phenolic Content and Antioxidant and Antimicrobial Properties of Fruits of Capsicum baccatum L. var. pendulum at Different Maturity Stages. J Med Food. 2008; 11(2): 267-274.

Kim S, Lee KW, Park J, Lee HJ, Hwang IK. Effect of drying in antioxidant activity and changes of ascorbic acid and colour by different drying and storage in Korean red pepper (Capsicum annuum, L.). Inter $J$ Food Sci and Technol. 2006; 41(S1): 90-95.

Lannes SD, Finger FL, Schuelter AR, Casali VWD. Growth and quality of Brazilian accessions of Capsicum chinense fruits. Sci Hortic. (2007); 112(3): 266-270.

Luo X, Peng J, Li Y. Recent advances in the study on capsaicinoids and capsinoids. Eur J Pharm. 2011; 650(1): 1-7.

Madail JCM, Schneid LF, Sima LF, Wendt AN. Economia da produção de pimenta vermelha no município de Turuçu-RS. Boletim de Pesquisa e Desenvolvimento. Pelotas: Embrapa Clima Temperado; (2005). 27 p.

Napoleão BA. Futuro promissor para a cultura de pimenta. Informe agropecuário: Cultivo de pimenta. Belo Horizonte, 27, 235, p. 3, 2006.

Park KJ, Yado MKM, Brod FPR. Estudo de secagem de pêra bartlett (Pyrus sp.) em fatias. Ciênc Tecnol Alimen. 2001; 21(3): 288-292.

Queiroz VAV, Berbert PA, Molina MAB, Gravina GA, Queiroz LR, Da Silva JA. Qualidade nutricional de goiabas submetidas aos processos de desidratação por imersão-impregnação e secagem complementar com convecção. Ciênc Tecnol Alimen. 2008; 28(2): 329340.

Raoult-Wack AL. Recent advances in the osmotic dehydration of food. Trends in Food Sci and Technol.1994; 5(8): 225-260.

Reifschneider FJB. Capsicum: pimentas e pimentões no Brasil. Brasília, DF: Embrapa Comunicação para Transferência de Tecnologia/Embrapa Hortaliças; 2000.

Reifschneider FJB, Ribeiro CSC, Carvalho SIC, Bianchetti LB, Cruz DMR, Makishima N, et al. Sistema de produção de pimentas (Capsicum spp.): Introdução e importância econômica. Brasília, DF: Embrapa Hortaliças, Sistema de Pordução, 4 ISSN 1678, Versão Eletrônica, Dezembro/2004.

Righetto AM, Beleia A, Ferreira SHP. Physicochemical stability of natural or pré-sweetened frozen passion fruit juice. Braz Arch Biol Technol. [online]. 1999; 42(4) . 
Sanjinez-Argandoña EJ, Branco IG, Takito SY, Corbari J. Influência de la desidratación osmotica y de la adición de cloruro de calcio en la conservación de kivis minimamente procesados. Ciênc Tecnol Alimen. 2010; 30(S1): 205-209.

Souza Filho MSM, Lima, JR Souza, ACR, Souza Neto MA, Costa MC. Efeito do branqueamento, processo osmótico, tratamento térmico e armazenamento na estabilidade da vitamina $\mathrm{C}$ de pedúnculos de caju processados por métodos combinados. Ciênc Tecnol Alimen. 1999; 19(2): 211-213.

Szczesniak AS. Texture is a sensory property. Food Qual Prefer. 2002; 13 (4): 215-225.

Vega-Gálvez A, Di Scala K, Rodríguez K, LemusMondaca R, Miranda M, López J, Perez-Won M. Effect of air-drying temperature on physico-chemical properties, antioxidant capacity, colour and total phenolic content of red pepper (Capsicum annuum, L. var. Hungarian). Food Chem. 2009; 117(4): 647-653.
Vega-Gálvez A, Miranda M, Clavería R, Quispe I, Vergara J, Uribe E, et al. Effect of air temperature on drying kinetics and quality characteristics of osmotreated jumbo squid (Dosidicus gigas). Food Sci Technol.2011; 44(1): 16-23.

Wyk, BE, Wink M. Medicinal Plants of the World. Portland, Oregon: Timber Press; 2004. 188p.

Received: May 11, 2011; Revised: September 27, 2011; Accepted: March 20, 2012. 
Página Em

Branco 